Doi: $10.31578 /$ jebs.v5i1.192

\title{
Impact Assessment of Perceived Curriculum Factors on Nigerian Students' Behaviour in Basic Science and Technology
}

\author{
Moses Olanrewaju Afuwape* \\ Funmilayo Adeola Adeyi**
}

\begin{abstract}
The National Policy on Education (Federal Republic of Nigeria, 2014) encourages teachers of basic science and technology to teach students for inculcation of the type of values and attitudes for the survival of the individual and the Nigerian society; the training of the mind in the understanding of the world around; and the acquisition of appropriate skills and the development of mental, physical and social abilities and competencies as equipment for the individual to live in and contribute to the development of the society. This study investigated the perceived influence of curriculum factors on Nigerian students' behaviour in basic science and technology. The study made use of survey design. Its population comprised of 50 basic science and technology teachers in public and private junior secondary schools in the selected local government area in Ogbomoso educational zone of Oyo state. A self-developed questionnaire on perceived curriculum factors in order to assess students' behaviour in basic science and technology was applied for data collection.

The instrument validated by Cronbach Alpha Reliability Coefficient method was employed to measure the reliability of the instrument. One research question and one null hypothesis guided the study. The results were analyzed using frequency count, mean and simple percentage, while T-test statistics was used to test the hypothesis at 0.05 level of significance. The findings of the study revealed no significant difference in basic science and technology constraints in teaching and learning at both public and private schools in Oyo state of Nigeria. The study, however, concluded that basic science and technology curriculum should be moderately accessible and necessary instructional facilities should be provided to qualified teachers to foster effective teaching and learning.
\end{abstract}

Keywords: Impact assessment; curriculum; behaviour; basic science and technology

\section{Introduction}

The Federal Government of Nigeria (2014) in its National Policy on Education states that education is the greatest investment that the nation can make for the quick development of economic, political, social and human resources. Generally in the whole world, particularly in Nigeria, education has been considered to be the corner stone for development. It forms the basis of literacy, skill acquisition, technological advancement and ability to harness human and material resources towards the achievement of societal goal (Federal Republic of Nigeria, 2014; Tianshan et al., 2007; Vali, 2013).

\footnotetext{
* Faculty Of Education, Olabisi Onabanjo University, Ago-Iwoye, Ogun State, Nigeria

** The College Of Education Lanlate, Oyo State, Nigeria.

Correcpnding Email: afuwapemoses@yahoo.com
} 
Nigerian education is under two proprietorships: governmental (public schools) and individual (private schools). Public schools are those schools that were established, managed, financed, as well as supervised by the government, while private schools (also known as independent schools) are schools whose affairs are under the control of a private entity. Public and private schools are monitored by the same regulatory authority, they follow the same curriculum under different conditions and sit for the same external examination which is organized by one body - West African Examination Council and National Examinations Council.

Among the school science education subjects is basic science and technology which is the main stream and focus of this study. Basic science and technology formerly referred to as integrated science is the bedrock and mother of science education. The subject was introduced into the Nigerian secondary schools as a panacea for some of the problems bedeviling science, especially at the junior level, especially with the revised policy on education with emphasis on the acquisition of skills. Basic science is a multidisciplinary course designed to resolve the issues of systematic ambiguity in teaching and learning of science (Afuwape, 2017). The need to emphasize science teaching and learning in schools stimulated UNESCO organize the first International Conference on the use of integrated approach in science teaching held in Droubja (Bulgaria) in 1968. This led to some measure of agreement that school science and technology should be concerned with promoting scientific and technological literacy (STL) for all (UNESCO, 2004). It is important to note that the developed nations attach a lot of importance to the teaching of school science subjects (Comber \& Keeves, 1973; Kyle, 1997; Muriithi et al., 2013).

Oni (2014) lamented that students' poor performance at the senior secondary school level indicates that they had not been properly trained in subjects like basic science and technology at the junior secondary 1,2 and 3 . This will definitely affect the development of science and technology of the nation.

The instrument used by public and private schools in Nigeria to dictate and disseminate learning activities is the curriculum. It is a dynamic and open document that is constantly changing with the needs, challenges and aspirations of the society.

In adequacies in the curriculum and use of the curriculum go a long way to affecting the goal of the subject, national policy of education and products of the school. There is no other reason for why this paper has been conceptualized.

\section{Methodology}

The study adopted a survey design. The sample involved fifty (50) Basic science teachers in selected public and private Junior Secondary schools in Ogbomoso Educational Zone of Oyo State.

The study adopts a multi-stage sampling approach. The first stage based on the existing grouping of the five local government areas in Ogbomoso Educational Zone of Oyo State. Out of the five Local Government Areas in Ogbomoso Educational Zone, three Local Government Areas purposively select which are Ogbomoso North, Ogbomoso South and Oriire Local Government Areas. Five public secondary schools out of fifteen and five private school schools out of thirty eight public secondary schools were purposively selected in Ogbomso North Local Government Areas, in Ogbomoso South Local Government Area, five public secondary schools out of sixteen public secondary and five out twenty three private secondary were purposively selected in Ogbomoso South Local Government Area. Likewise in Oriire Local Government Area, five out eighteen public secondary schools and five out of seven private Secondary Schools purposively selected making total of fifteen public secondary schools and fifteen private secondary schools in Ogbomoso Educational Zone. 50 Basic science and technology teachers were used for the study and Basic science and Technology Curriculum Questionnaire (BSTCQ) 


\section{Basic Science Curriculum Questionnaire (BSCQ)}

The Basic Science Curriculum Questionnaire (BSCQ) is an instrument developed to elicit information from Basic Science Teachers on Basic Science and Technology Curriculum constraints to the teaching and learning of Basic Science and Technology in public and private schools. For this study, the self-structured instrument was designed to elicit information from Basic Science and Technology Teachers. The instrument contains 25 items. The instrument is in 4 Likert scale type such as strongly Agree (4), Agree (3), Disagree (2), Strongly Disagree (1). Section C consists of some items which the basic science and technology teachers responded to by showing their level of agreement. The BSCQ was administer to basic science teachers in selected schools.

The reliability of the instrument (BSTCQ) was determined using Cronbach Alpha reliability statistics to produce the reliability coefficient of 0.78 and the data was analysed with the use of mean, simple percentage and T-test.

\section{Research Question}

What is the Basic Science Curriculum constraint to teaching of Basic science and technology in public and private secondary schools in Oyo State?

Table 1. Means and percentages of respondents on basic science and technology curriculum constraints

\begin{tabular}{|c|c|c|c|c|c|c|c|c|c|}
\hline$/ \mathbf{N}$ & ITEMS & $\begin{array}{l}\text { Mean of } \\
\text { SA (PUB } \\
\text { SCH) }\end{array}$ & $\begin{array}{l}\text { Mean of SD } \\
\text { (PUB.SCH) }\end{array}$ & $\begin{array}{l}\text { Mean of SA } \\
\text { (PRV.SCH) }\end{array}$ & $\begin{array}{l}\text { Mean of } \\
\text { SD } \\
\text { (PRV.SC } \\
\text { HL) }\end{array}$ & $\begin{array}{l}\text { \% of SA } \\
\text { (PUB.S } \\
\text { CH) }\end{array}$ & $\begin{array}{l}\text { \% of SD } \\
\text { (PUB.SCH } \\
\text { ) }\end{array}$ & $\begin{array}{l}\text { \% of SA } \\
\text { (PRV.S } \\
\text { CH) }\end{array}$ & $\begin{array}{l}\% \text { of } \\
\text { SD } \\
\text { (PRV. } \\
\text { SCH) }\end{array}$ \\
\hline 1. & $\begin{array}{l}\text { Too elaborate basic } \\
\text { science and } \\
\text { technology syllabus }\end{array}$ & 13 & 12 & 13 & 12 & 52.00 & 48.00 & 52.00 & 48.00 \\
\hline 2. & $\begin{array}{l}\text { Inadequate basic } \\
\text { science laboratory } \\
\text { facilities }\end{array}$ & 17 & 8 & 17 & 8 & 68.00 & 32.00 & 68.00 & 32.00 \\
\hline 3. & $\begin{array}{l}\text { Conduct of } \\
\text { practical in basic } \\
\text { science and } \\
\text { technology is not } \\
\text { easy due to } \\
\text { inadequate } \\
\text { laboratory facilities }\end{array}$ & 17 & 8 & 20 & 5 & 68.00 & 32.00 & 80.00 & 20.00 \\
\hline 4. & $\begin{array}{l}\text { Unable to take } \\
\text { student to }\end{array}$ & 8 & 17 & 16 & 9 & 68.00 & 32.00 & 63.00 & 36.00 \\
\hline
\end{tabular}




\begin{tabular}{|c|l|l|l|l|l|l|l|l|}
\hline & $\begin{array}{l}\text { excursions and field } \\
\text { trip. }\end{array}$ & & & & & & & \\
\hline 5. & $\begin{array}{l}\text { Non } \\
\text { encouragement of } \\
\text { Junior Engineers } \\
\text { Technology Club } \\
\text { (JET CLUB) } \\
\text { competition }\end{array}$ & 4 & 15 & 0 & 56.00 & 44.00 & 60.00 & 40.00 \\
\hline
\end{tabular}

Based on the result of this study, answer from Basic Science Curriculum factor Questionnaire (BSCFQ) respondents as shown in the Table 1 indicates the major constraints of Basic science curriculum to the teaching of Basic science and technology.

1. The syllabus of Basic Science and Technology is too elaborate. The percentage of those that agreed on this in both public and private schools is $52.00 \%$ and $52.00 \%$ respectively.

2. Inadequate laboratory faculties. The percentage of those who agreed in public schools is 68.00 while that of private schools is $32.00 \%$.

3. Conduct of practical in Basic science and technology is not easy due to inadequate laboratory facilities. The percentage of those who agreed in public schools is $68.00 \%$ while in private schools is $80.00 \%$,

4. Inability of teachers to take on excursions or field trips. Percentage of those that agreed on this in public schools in $68.00 \%$ while in private schools is $63.00 \%$.

5. Non encouragement of Junior Engineers Technology Club (JET CLUB) competition. Percentage of those that agreed on this public school is $56.00 \%$ while $60.00 \%$ in private schools.

Table 2. Independent Samples Test, basic science and technology curriculum factor

\begin{tabular}{|c|c|c|c|c|c|c|c|c|c|}
\hline & \multicolumn{2}{|c|}{$\begin{array}{l}\text { Levene's Test for } \\
\text { Equality of } \\
\text { Variances }\end{array}$} & \multicolumn{7}{|c|}{ t-test for Equality of Means } \\
\hline & \multirow[t]{2}{*}{$\mathrm{F}$} & \multirow[t]{2}{*}{ Sig } & \multirow[t]{2}{*}{$T$} & \multirow[t]{2}{*}{ Df } & \multirow[t]{2}{*}{$\begin{array}{l}\text { Sig. (2- } \\
\text { tailed) }\end{array}$} & \multirow[t]{2}{*}{$\begin{array}{l}\text { Mean } \\
\text { Difference }\end{array}$} & \multirow[t]{2}{*}{$\begin{array}{l}\text { Std. Error } \\
\text { Difference }\end{array}$} & \multicolumn{2}{|c|}{$\begin{array}{l}95 \% \text { Confidence interval } \\
\text { of the Difference }\end{array}$} \\
\hline & & & & & & & & Lower & Upper \\
\hline $\begin{array}{l}\text { CURRICULUM } \\
\text { Equal } \\
\text { variances } \\
\text { assumed } \\
\text { Equal } \\
\text { variances } \\
\text { not assumed }\end{array}$ & .078 & .781 & $\begin{array}{l}-1.576 \\
-1.576\end{array}$ & 47.882 & .122 & -1.12000 & .71068 & -2.54901 & .30892 \\
\hline
\end{tabular}


The p-value (0.122) is greater than 0.05 , hence we fail to reject Ho and conclude that there is no significant difference in the Basic science curriculum constraints to the teaching of Basic science and technology in public and private secondary schools in Oyo State. Therefore the null hypothesis is hereby accepted.

\section{Basic science and technology curriculum constraints to teaching of basic science and technology in Oyo state}

The findings of this study revealed that there is no significant difference in Basic Science and Technology curriculum constraints to the teaching of basic science in public and private schools in Oyo State. The result of the research question revealed that the respondent in public and private school agreed that the syllabus of Basic Science and Technology is too elaborate, inadequate laboratory facilities were observed and inability of teachers to break curriculum down to sub smaller units effectively, unable to take students to field trips. This is in agreement with the views of Okpala (2011), Akpan (2012), Abakpa (2013), Oludipe (2011), Afuwape (2017), and Onanuga and Saka (2018). Presently, Integrated Science is taught with little or no science equipment, materials, laboratories and other essential infrastructures for easy transfer of knowledge and understanding of the students, also to realize the goal of the 9-year Basic Education Curriculum (BEC). The relevant materials that will aid the effective delivery of the curricula content in schools should be provided. Such materials include computers, functional laboratories, learner-centered textual materials prepared by Nigeria Educational Research and Development Council (NERDC) and some publishers to generate learners' interest and challenge in innovative and creaking thinking. Telu (2016) said that any topic or content that is not covered at any stage will hamper the understanding of the next topic in the upper stage. There have been a long lasting competition between the private and public schools. The coverage of integrated science scheme of work is a task that involves the learner, the teacher and the entire school system. The important thing in terms of teaching and learning is the coverage of subject content and not consider if it is a privately owned school or Government owned school. Since the quality of education do not depend on the structure and name of a school but how well the students are being taught. The structures and appropriate activities that foster effective implementation of the curriculum are either inadequate or lacking in Nigerian schools. Foremost among the myriad of challenges of Basic Education in Nigeria are the issues of teacher quality and development, lack of enough specialist teachers; dearth of relevant support materials for teachers and inadequate supervision and monitoring of teachers. Basic Education teachers are also being trained and retrained in their subject areas on continuous basis, and resources are being provided for the acquisition of consumables and non-consumable items required for teaching and learning for the curriculum contents. This work and others mentioned above presented consistent findings and no other studies presented different view against the above. Meaning that complexity of the curriculum has been a constraints militating against the impact the Basic Science Technology as a subject would have created. In view of the above, the study recommends that

- Government should wake up to her responsibilities most especially in the area of Science and Technology Education.

- Qualified basic science and technology teachers should be appointed in both public and private schools.

- Basic science and technology teachers should attend seminars and workshops in order to update themselves with the current trends in the world of science education.

- Basic science and technology curriculum should be moderate and necessary facilities should be provided to foster teaching and learning of the subject. 


\section{References}

Abakpa, B.O. \& Agbo-Egwu, A.O. (2013). Challenges of Attaining MDGs in Nigeria through Mathematics Curriculum Delivery. In Attaining the MDGs through STEM Education, Proceedings of $54^{\text {th }}$ Annual Conference of STAN, 31-37. Nigeria.

Afuwape, M.O (2017). Taking proactive national development in its strides: A speculative peep at emerging trends in science and technology education as a sure panacea. British Journal of Education, 5 (3), 43-50.

Akpan, B.B. (2012). Nigeria and the Future of Science Education. Oluseyi Press Ltd Ibadan.

Comber, L.C. \& Keeves, J.P. (1973). Science Education in Nineteen countries: International Studies in Evaluation. Stockholm: John Beiley and Sons.

Federal Republic of Nigeria (2014). National Policy on Education. Lagos: NERDC.

Kyle, B.K. \& Walbery, H.J. (1981). The imperative undergraduate education in science, mathematics, engineering and technology. Journal of Research in Science Teaching, 34,557-549.

Muriithi, E.M., Gunga, S.O., Ngesu, L.M., K'Odhiambo, A.K., \& Wachira, L.N. (2013). School Characteristics, use of project method and learner achievement in physics. Journal of Education and Practice, 14(8), 196-294.

Okpala, P.N. \& David, U.E. (2014). Factors affecting teaching and learning of basic science and technology in primary schools. Journal of Education Policy and Entrepreneurial Research (JEPER), 1(1). 46-58.

Oludipe, D.I. (2011). Developing Nigerian integrated science curriculum. Journal of Soil Science and Environmental Management, 2(8), 134-154.

Onanuga, P.A \& Saka, A.O. (2018). Trend analysis of students' academic performance in selected science, technology, engineering and mathematics subjects in Ogun state basic education certificate examination (OG-BECE), Nigeria, from 2011 to 2015: A Projection for Five Years. International Council of Association for Science Education, 29, 110-116.

Oni J.O. (2014). Teacher quality and student academic achievement in basic technology in junior secondary schools in South-West Nigeria. Journal of Educational and Social Research, 4 (3), 397-402.

Telu, H.E. (2016). A comparison between public and private schools' coverage of science scheme of work in upper basic secondary education curriculum in Nigeria. British Journal of Education, Society \& Behaviour Science 16(1): 1-9

Tianshan, Z. Runyong, Y.Y., Xiaomei, Z., Zhaohui, C., \& Xiejing, L. (2007). Balanced development of compulsory education: Cornerstone of education equity. Frontiers of Education in China, 2 (4), 469-493.

UNESCO (2004). Educational Development in Africa. Paris: UNESCO.

Vali, I. (2013). The Role of Education in the Knowledge-based Society. Procedia - Social and Behavioral Sciences, 76 (15), 388392. 